ントラスト向上に㕕く用いられている，われわれはMTC併用時にお ける頭部TOF MRAの血液通過時間 (Transit Tıme) と最適Flip Angleの 関係について，非併用時と比較恰討を行ったので報告する。

【方法】Transıt TımeおよびSpoiled Grass 法のFlıp Angle変化時におけ る血管の信号強度，脳実質のMTC併用と非併用時に掞ける信号強度 変化を計算しシミュレーションを行い,さらに臨床において撮像を 行った。使用機種は超伝導型MR装置S Signa Horizon (GE社, 静磁場強 度1.5T)である。

【結果および考察】Transit Time 300msにお计る血管と大脳白質のコン トラストはMTC併用で 0.104 , 非併用で 0.056 となり約 2 倍となっ た。MTCを併用しない場合はTransit Time 500ms以上ではすべての Flip Angleにおいて血管とのコントラストを得ることはできない。一 方, MTC併用ではTransit Time 100-600msに扔いて最適化により良好 なコントラストを得ることが可能であった，頭部血管の描出におい てMTC pulseの有效性については知られているが，さらに本検討か らMTC併用時に㧍けるFlip angle の設定が血液通過時間の長い末梢 血管の描出に重要であることが示された。

181 頭部領域における $3 \mathrm{TMR}$ 装置の撮影パラメー夕の最適化一 1.5 Tとの比較一

福井医科大学医学部附属病院・放射線部 藤原康博, 北章延 福屋裕子, 石森佳幸, 森 光一, 東村享治

福井医科大学 高エネルギ一医学研究センター 山田和弘, 米倉義晴 藤林康久

GE横河メディカルシステム(株) 松田 豪，平田直樹

【目的】3Tの静磁場強度を持つMRI装置は, 磁場特性によって高いS/N を持つために理論的には1.5Tの 2 倍のSNRが得られる。しかし，生 体においては，さまざまな因子によって単純に2 倍のSNRが得られ ないことが推測される，そこで，基礎的な検討として実際の臨床画 像を1.5Tと同一パラメータを用いて3Tで撮像した場合に画質がどの 程度改善するか比較検討したので報告する。

【万法】MR装置はGE社製Signa VHı 3Tver.8.3およびSıgna Horizon 1.5Tver58を用いた。1.5Tと3Tにおいてそれぞれ同一の撮像パラ メータを用いて健常ボランティアの頭部 $\mathrm{T} 1$ 強調画像 (SE, TR/ $\mathrm{TE}=335 / 14 \mathrm{~ms})$ およびT2強調画像 $(\mathrm{FSE}, \mathrm{TR} / \mathrm{TE}=3200 / 85 \mathrm{~ms}, \mathrm{etl}=16)$ を 撮像した。 そして，その画像に抢ける白質，灰白質，脳脊髄液のコ ントラスト，CNRおよびSNRを测定した。

【結果】1.5Tと比較して3Tでは，T1強調画像，T2強調像のいずれにお いても白質のSNRは150\%向上し，白質と灰白質のCNRは約200\%向 上した。しかし，灭白質と脳脊髄液のSNRはそれぞれT1強調画像で 約150\%，230\%であったのに対して，T2強調画像では，どちらの組 織もSNRはほとんど変化しなかった。また，組織ごとのコントラス トはT1強調像およびT2強調像のいずれも低下した。

【考察】1.5Tと同一のパラメータを用いた場合, 組織ごとのコントラ ストは低下した。その原因としては，磁場強度が高くなったことに よる生体のT1值の延長などが考えられる，実際にT1值は疢白質では

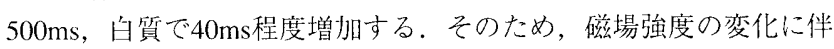
う撮像パラメータの最適化が必要なことが示唆された。

182 SENSE-reference scanの違いが折り返し補正効果に与える影 響について

東海大学医学部付属病院・放射線技術科 木村絵里, 室伊三男

堀江朋彦、松尾太一, 花木 昭

【目的】折り返しの補正精度を左右する因子として，感度分有を得る ためのreference scanに注目し, reference scan 撮影時のFOV・スライ ス厚・Matrix数が折り返しの補正効果に与える影響について検討し たので報告する．

【使用機器】PHILIPS社製INTERA (Master)， $\mathrm{N}_{1} \mathrm{SO}_{4}$ 液ファントム, 自
作解析プログラム

【方法】Mult channel array collを用い, reference scanにおけるFOV・ スライス厚・Matrix数をそれぞ机変化させ，折り返し補间效果につ いて検討した。

【結果】スライス厚を薄くしてスライス枚数を多くし，FOVを小さく してMatru数を多くすると，折り返しの補正精度は向上した。 reference scanの違いによる補正精度の养は，各コイルのGeometry factorに依存して顕著に垷れた。

【考察】感度分布の測定は, より細かく行うほど折り返しの補正效果 が良好であった，その理由として，本装置での感度分布の测定は3D 撮影で行って抢り，任意の断面でのコイル感度マップをMPRによっ て求めていることが理曲と考える。市わちMPRによって求めた感 度マップの精度がreference scanの分解能と面接関係しているものと 考察する。

183 PAT法における撮像パラメータの検討

虎の門病院・放射線部高橋順士，吉原千治，濱田祐介，田野政勝 関みさよ, 吉田 孝, 村本直樹, 渋谷清和, 森內啓三郎, 竹部英紀 【目的】Parallel ımagnngの一つであるParallel Acquisıtion Technıques (PAT)法における時間短縮，アーチファクトと信号雑湆比の関係に ついて検討を行ったので報告する.

【方法】MRI装置はSIEMENS社製MAGNETOM Symphony1.5T使用 した.PAT法のパラメータのうち, PATファクター(リダクション

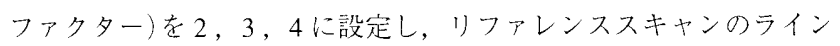
数をそれぞれ 15 から 250 まで変化してファントムを撮像した。撮像 したファントムの撮像時間, 画像再構成時間, アーチファクトと信 号雑音比の関倸について比較した。またリコンストラクションの modıfied SENSitivity Encodıng (mSENSE) とGeneRalızed Autocalıbratıng Partially Parallel Acquisition(GRAPPA)の 2 種類についても比較した. 【結果】TR163ms, TE4 76ms, FA70 , Matrux256×256のFLASH法に おいてno PAT法では，撮像時間は42秒であったが，PATファタター 4 でリファレンススキャンのライン数が15のとき撮像時間は13秒に 短縮したが，アーチファクトが多く，信号雑音比は極端に低下し た。また，同じ設定パラメータでは, GRAPPA法が, MSENSE法に 比ベ, アーチファクトが少なく，信号雑者比が高い傾向であった。 【考察】PAT法では, リファレンススキャンと本スキャンを同時に撮 像するため, リファレンススキャンのライン数が，撮像時䦓，アー チファクトと信号雉音比に深く関与していると考えられる。 そのた め, 撮像時間の短縮とアーチファクトや信号雑音比の低下などの卜 レードオフを考慮したパラメータの設定が重要と考えられる。

184 Parallel Acquisition Techniqueにおける金属アーチファクト の検討

東京都江東高齢者医療センタ一・放射線科 濱崎 望, 高橋将信

高瀬 誠，木村 聡，木暮陽介，佐藤謙一，熊谷芳幸

【目的】Parallel Acquisition Technıque(PAT)には, mSENSE(イメージ ベースアルゴリズム)とGRAPPA(Kスペースベースアルゴリズム)の 2 種類あり, 撮像部位・断面により画者の使い分けを行っている. 今回, mSENSE・GRAPPA撮像時に扔ける金属アーチファクトにつ いて検討したので報告する。

【使用装置】SIEMENS MAGNETOM Symphony

【方法】均一ファントムに金属球を固定したものを用い, MSENSE · GRAPPA techniqueを併用したSpin echoとGradient echoにて，リファ レンスライン数・位相エンコード方向を変化させ, アーチファクト の大きさ・形状・方向をnon PAT時と比較検討を行った。

【結果・考察】Spin echoにおけるmSENSE・GRAPPAは, 同一形状の アーチファタトを描出し，リファレンスライン数を増加させると non PAT時に近い画像を示亦改善傾问にあった。 Gradient echoにおけ 
るGRAPPAは，Spin echo同様の傾向にあるが，mSENSEにおいては non PAT時とのアーチファクト画像に差が見られ，リファレンスラ イン数を増加させても改善される傾向ではなかった。これは mSENSEが実空間での感度の推定を行うことにより，局所的な磁場 の歪みや欠損があるとリファレンスライン数を増やしても，久損部 周辺の推定が问上していないことが考えられる。

185 PPA(Partially Parallel Acquisition)法による空間分解能の検 討

\section{奈良県立医科大学附属病院 进司，野儀明宏，勝真康行}

【目的】PPA法は，多少SNRは低下するものの分解能を変えることな く撮像時間を短縮させる方法として広く普及する傾向にある。当院 においても，冠状断方向にて使用可能なGRAPPA法を用いて主に血 管撮影にて活用している(第59回総会学術大会：2003年4月)。しか しながら，GRAPPA法を使った冠状断CE-3DMRA門脈造影撮像にお いて，抹梢静脈の描出能が低下しているように見える症例に遭遇し た。そこで，PPA法の特徴である撮像時間を半分にしても(実際には reference scanがあるので1/2にならない)SNRが低下するだけで分解 能が低下しないといわれているが，臨床にて三次元撮像法を使った 血管描出に使用するにあたって，スライス厚やPAT factorが微細血. 管の描出能にどのように影響を拉よぼしているのかを検討した。 【方法】希釈造影剂を充填した内径 1 的mのチューブを, CE-3D MRA撮像法に使用する3D FLASHシーケンスを使ってGRAPPA法を 併用した冠状断面にて, PAT factorとスライス厚を恋化させ抹梢血 管に見立てたカテーテル内の希䣋造影剤のSNRとコントラストを測 定し, スライス方向の分解能に対する微細血管の描出能を評価し た。また，臨床におけるGRAPPA法併用CE-3D MRAについても検討 を加えた。使用装置は, SIEMENS社製Symphony Maestroである。 【結果】撮像スライス厚が薄くなりPAT factorが大きくなるほどチュー ブの描出能は低下した。これは, 通常撮像条件の高分解能化がもた らす微細組織の描出が，PPAの使用によりSNRの低下の方が総合的 に画像コントラストの低下を引き起こし, 結果的に微細血管の描出 能が低下したと思われる。

186 SPEEDER法を用いたTrue SSFPシーケンスの特性 宮崎医科大学医学部附属病院 ·放射線部長瀬一輝, 上田正美 紫垣誠哉

\section{古賀駅前クリニック・放射線技術部 黒岩靖淳}

【はじめに】新しい超高速撮像法であるTrue SSFPは, gradient echo (GRE) 法の一つで, Steady Stateの状態にあり, 高信号画像拉よび, 超高速撮像を可能にしている。また, SPEEDER法(東芝製・Parallel imaging法)は, 複数の受信コイルで信号をパラレル(並列)に受信し て処理することで撮像時間の大幅な短縮を図る高速撮像技術であ る.このTrue SSFPとParallel imaging法との併用は, 非常に効果的で あり，更に高速撮像を可能にしている。

【目的】今回は, True SSFPシーケンスの撮像や画質特性などに関する 基礎的実験を行った。また，SPEEDER法を用いた場合のTrue SSFP シーケンスについても同様の実験を行い, 併用法の有用性および撮 像の最適化に関する検討を行った。

【実験方法】1. GRE法がRFパルスのFlip angle(FA)で, 画像のコント ラスト, 信号強度が変化してくるので, True SSFPのFAを変化さ せ，水と脂肪のSNRを測定した。2. True SSFPは，強いT2強調画像 が撮像できると同時に，流れに強く，流速のある血管などの描出も 可能である，そこで，ファントム内の水の流速を変化させ，流速に 対する感度を知るためにSNRを測定した３. SPEEDER法では， reduction factor (speeder factor ・高速化率)により撮像時間が変化する ため，この值を変化させた時のTrue SSFPのSNRを測定した。

【実験結果・まとめ】今回の実験により, SPEEDER法併用時でのTrue
SSFPのSNRなど諸特性を解析することにより，画像の最適化を行う ことができた，尚, 詳しい結果や臨床画像などについては, 発表に より報告させて頂きます。

187 SPEEDERによる3D FASE MR Cisternographyの画質改善 に関する検討

香川医科大学医学部附属病院・放射線部 石森隆司，朝原正喜 楠原俊明

香川医科大学医学部附属病院・放射線科 中野 覚 さぬき市民病院・放射線科 井原正治，高嶋義昇，高橋一枝 東芝メディカル(株) 山下裕市

(株)東芝那須工場 杉浦 聡

【目的】FASE 3D法では, 多Shot化㧍よび長めのTR設定がBlurringの低 減，SNR向上などの画質向上に有用である。しかし，どちらにおい ても撮影時間の延長を伴う。パラレルイメージングは高速化率を上 げることによるSNRの低下が問題とされているが，ETLが短縮され るため，Blurringの低減だけでなく，TRの短縮化，SNRの向上に寄 与すると考えられる。また，TRの短縮化は撮影時間を低減させるこ とができ，短時間での多Shot収集も可能と考えられる。これらの点 よりFASE 3D法にSPEEDERを用いることによる画質改善の検討を行 j.

【方法】、ファントム実験にて，TR一定での高速化率の違いによる 信号変化を求める. 2. SPEEDERの有無掞よびShot数の増玑による Blurring の改善, 画質評洒を行う. 3. 高速化率, Shot数の違いによ る, 脳脊髄液の回復時間の比較を行う４４ボランティアでMR Cisternographyの撮像を行い，画質評価を行う。装置は東芝社製 EXCELART AG 1.5Tを用い，コイルはQDヘッドSPEEDERにて撮 像を行った。

【結果】ファントム実験に扔いて，3DFASE法は短いTR時において， 高速化率の上昇によりSNRの上昇が見られた。T2 plusを用いた $3 \mathrm{D}$ FASEの場合, 高速化率, Shot数が大きいほど，脳脊髄液の回復時間 短くなり，Blurrlingに関しても低減され画質改善が見られた。

【結論】パラレルイメージのメリットは高速化のみでなく, 3D FASE MR CisternographyにおけるBlurringの減少やSNRの间上など，画質改 善においても効果があると考えられる。

\section{PAT法を用いた脊惆MRIの検查時間知縮の検討} 虎の門病院·放射線部 森内啓三郎, 高橋順士, 吉原千治, 濱田祐介 田野政勝, 関みさよ，吉田 孝，村本直樹，渋谷清和，竹部英紀 【目的】Parallel Acquisition Techniques(PAT) 法では, リコンストラク ションアルゴリズムとして, modified SENSitıvity Encoding (mSENSE) とGeneRalized Autocalibrating Partially Parallel Acquisition (GRAPPA)の 2 種類がある。それぞれSENSE法とSiMultaneous Acquisition of Spatial Harmonics (SMASH) 法の発展型であり, Parallel imagingの一つである. 今回われわれは，PAT法を用いて脊髄ルーチ ン検査の時間短縮について検討を行ったので報告する.

【方法】MRI装置はSIEMENS社製MAGNETOM Symphony $1.5 \mathrm{~T}$ を使用 した。脊髄ルーチン検査では，サジタル面のT1，T2強調画像とアキ シャル面のT1, T2強調画像を撮像している。今回PAT法を用い, PATファクター(リダクションファクター)を 2 に設定し, リファレ ンススキャンのライン数を变化させて撮像時間, アーチファタトと SNRの関係についてファントムとボランティアで撮像して比較検討 した.

【結果】リファレンススキャンのライン数が少ないほど撮像時間は短 縮し，SNRは低下したがアーチファクトはみられなかった。逆にラ イン数を増やすほどSNRの低下は少なくなり, 撮像時間は延長し た。これらを踏まえ，それぞれの撮像で約 2 分の撮像パラメー夕の 設定が可能となり，検査時間も約 10 分となり，スループット向_上に 